Research Article

\title{
Effect of Exposure to Pasteurella multocida B:2 and its Immunogens on Clinical, Hematological and Serum Biochemical Parameters in Neeli Ravi Buffaloes
}

\author{
Ali Zaman', Nabila Roohi ${ }^{1}$ and Muhammad Irfan ${ }^{2 *}$ \\ ${ }^{1}$ Department of Zoology, University of the Punjab New Campus Lahore, Pakistan; ${ }^{2}$ Departrment of Biotechnology, University \\ of Sargodha, Sargodha, Pakistan.
}

\begin{abstract}
Buffaloes and other bovines suffer from a fatal disease, "Hemorrhagic septicemia" (HS), which is produced by a gram-negative bacterium "Pasteurella multocida." Existing literature has established bacteria's pathogenesis, but still, the literature about the role of bacteria and its immunogens on the demonstration of clinical signs, hematology and serum biochemistry in Nili Ravi buffaloes under subtropics is lacking. This study was designed to fulfill this gap by analyzing the effects of exposure to the bacterial culture of Pasturella multocida (P. multocida) type B:2 and its immunogens, i.e., lipopolysaccharide (LPS) and outer membrane protein (OMP) on Nili Ravi buffaloes. Prepubertal Nili Ravi female buffaloes ( $\mathrm{N}=18)$ of 10-12 months age in good health condition were divided into five treatment groups $(n=3$ each) and a control group $(n=3)$. Treatment groups' animals were exposed to P. multocida bacterial culture and its immunogens, i.e., LPS (oral and intravenous) and OMP (oral and subcutaneous). Animals were analyzed for the development of clinical signs, hematology and serum biochemistry. All treatment groups exhibited clinical signs (ranging from mild to acute) like increased temperature, variation in rumen motility, mucous membrane, salivation, edema, dullness, depression, nasal discharge, respiratory distress and recumbence or death. A significant change in complete blood count $(\mathrm{CBC})$ including packed cell volume (PCV), hemoglobin ( $\mathrm{Hgb})$ concentration, red blood cells (RBCs) count, mean corpuscular volume $(\mathrm{MCV})$, mean corpuscular hemoglobin $(\mathrm{MCH})$, mean corpuscular hemoglobin concentration (MCHC) platelets count, mean platelet volume (MPV), white blood cells (WBCs) count, monocytes count, lymphocytes count and granulocytes count. Serum biochemistry profiles (total protein, Albumin and creatinine) of treatment group animals were also changed significantly. Cumulatively it was revealed that P. multocida B: 2 and its Immunogens (LPS and OMP) affect the hematology and serum biochemistry profiles of Neeli-Ravi buffaloes. These findings prove that OMP and LPS from P. multocida B: 2 may be considered for vaccine development.
\end{abstract}

Received | January 21, 2021; Accepted | March 25, 2021; Published | June 02, 2021

*Correspondence| Muhammad Irfan, Departrment of Biotechnology, University of Sargodha, Sargodha, Pakistan; Email: irfan.biotechnologist@ gmail.com

Citation | Zaman, A., N. Roohi and M. Irfan. 2021. Effect of exposure to Pasteurella multocida B:2 and its immunogens on clinical, hematological and serum biochemical parameters in Neeli Ravi buffaloes. Sarhad Journal of Agriculture, 37(2): 666-674.

DOI | http://dx.doi.org/10.17582/journal.sja/2021/37.2.666.674

Keywords | Neeli-Ravi Buffaloes, Hemorrhagic septicemia, Pasteurella multocida B:2, Immunogens, Lipo Poly Saccharide (LPS) and Outer Membrane Proteins (OMP)

\section{Introduction}

$\mathrm{B}$ uffalo is considered the main dairy animal in Pakistan. Almost $76 \%$ of total buffaloes are found in Punjab and the remaining 24\% of the buffaloes are found in other provinces (Anonymous, 2019-20). The total number of buffaloes in Pakistan is 41.2 Million, while $73 \%$ of the national milk production 
is contributed by Punjab, out of which $60 \%$ of the milk is obtained from buffaloes. In Pakistan, buffaloes are kept in a traditional small farming system and the farming is also integrated with the production of crops. It is believed that $85 \%$ of the farmers are keeping a herd of one to five animals. $70 \%$ of milk production is contributed by 0.5 Million landless farmers in Pakistan (Chung et al., 2016).

HS is considered endemic in Pakistan and costs heavy economic losses to the livestock farmers every year. HS has been reported globally, excluding UK, Australia and various other European countries (Othman et al., 2016). HS is an extraordinarily catastrophic disease of bovines in humid states. Specific serotypes of $P$. multocida are predominant in peculiar geographic zones. Serotype B:2 is predominant in Asian countries, while serotype E:2 is prevailing in African countries (Saad et al., 2013).

HS mostly occurs in acute form; however, sub-acute and chronic forms are also not very infrequent. Initially, there is an increase in rectal temperature, which often goes undetected. Afterward, respiratory distress, excessive salivation, fatal septicemia, and eventually recumbence result in the animal's death. The usual incubation period of this disease is $1-3$ days, but sudden death without any observable clinical signs may also happen (De Alwis, 1999). The acute form of HS onsets all of a sudden and causes death within 24 hours. The animals exhibit an unusual increase in rectal temperature $\left(105-107^{\circ} \mathrm{F}\right)$, cyanosis of visible mucus membranes and weak pulse coupled with dyspnea (Benkirane and De Alwis, 2002). The sub-acute form of HS is described by bronchopneumonia and edema at the throat/brisket region. The progression of HS infection takes a longer time in the chronic form. The exhibited signs include dyspnea and mucopurulent/ bloody nasal discharge (OIE, 2009).

HS is believed to be the most dangerous and there are rare chances of cattle being recovered from it once its clinical signs appear. The most probable way to control this disease in endemic countries is through preventative vaccination programs. The vaccination's effectiveness could be enhanced by immunization of animals before the disease period's onset (Shivachandra et al., 2011). There are two serotypes (B: 2 and E: 2) of Pasteurella, which cause HS. In Pakistan and other Asian countries, B:2 is prevalent (Ibrahim et al., 2016).
Essential factors which contribute to the virulence of $P$. multocida include lipopolysaccharides (LPS), outer membrane protein (OMP), P. multocida toxins (PMT) and its capsule (Kubatzky, 2012). All of these virulent factors can activate the systemic immune response by the host. LPS has been described as an important component of gram-negative bacteria. $P$. multocida is also a gram-negative bacterium and based on dissimilarities in LPS composition, its 16 types have been established (Harper et al., 2011). Based on variation in bacterial capsules' antigenicity, $P$. multocida has been divided into five serogroups, i.e., A, B, D, E and F (Wilson and Ho, 2013). OMPs of $P$. multocida have been categorized based on their structure and immunogenicity. These proteins are believed to mediate the host immune response through cytokine production (Iovane et al., 1998).

As this disease causes sudden death despite antibiotic and serum therapies, vaccination programs are the only solution to lessen this disease's impact (De Alwis, 1999). Extensive vaccination control programs are being implemented to control this disease in endemic areas. Such programs are very important to curtail the animal death rate and economic losses cause by this disease. Presently HS is being controlled by broth vaccine and oil adjuvant vaccine. Broth vaccine is used for rapid coverage in outbreak areas and oil adjuvant vaccines are used in adjacent areas. In South Asian countries, a live attenuated vaccine is suggested preceding monsoon season (Zamri-Saad and Annas, 2016). Difficulties in gathering animals for an injectable vaccine in case of small holdings and the possibility of negative effects like a sterile abscess, localized swelling, and post-vaccination shock are some important concerns related to oil-adjuvant vaccines against $\mathrm{HS}$ (Rafidah et al., 2010).

Oral bacterial culture vaccines and injectable vaccines based on $P$. multocida immunogens may prove beneficial to be used in bovines. Recently investigations in Malaysia have stated the stimulation of host cell response in buffaloes against oral/ subcutaneous exposure to bacterial culture (Chung et al., 2015). A similar study has reported severe distress and ultrastructural changes in the gastrointestinal, urinary tract and respiratory system of buffaloes on subcutaneous administration of $5 \mathrm{ml}$ of $P$. multocida type B:2 $\left(10^{9} \mathrm{CFU} / \mathrm{ml}\right)$ suspension (Annas et al., 2015). 
Another study on oral and subcutaneous inoculation of OMP extract of $P$. multocida type B: 2 has resulted in significant differences in hematology and biochemistry profiles of experimental buffaloes (Chung et al., 2016). In a recent study, in-vitro exposure of $P$. multocida type B:2 and its LPS endotoxins has resulted in ultrastructural changes in buffaloes' endothelial cells (Puspitasari et al., 2020).

Mice have been extensively used as an experimental animal in pathogenesis studies against capsular type A or B of P. multocida (Harper et al., 2006). Intraperitoneal inoculation of mice with a very small dose of P. multocida organisms (20 CFU) has caused its death within 24 hours (Ramdani et al., 1990; Biswas et al., 2004). The geographical distribution of $P$. multocida serovars is well established, but no differences in virulence of these serotypes have been reported (De Alwis, 1999).

A study on rabbits inoculated subcutaneously with LPS extract of $P$. multocida has established a correlation between improved antibody titer and an increased LPS antigen dose (Ashraf et al., 2014). An inclusive proteome analysis study of sarcosineinsoluble membrane segments has demonstrated a substantial role of $P$. multocida OMP-based vaccine in providing cross-protective immunity (Boyce and Adler, 2006).

P. multocida causes fowl cholera in poultrybirds. Outer membrane protein gene $(o m p H)$ has been reported as a strong immunogen of $P$. multocida in poultry birds. A recombinant vaccine has been devised for the poultry industry using Escherichia coli plasmid-encoded with ompH-gene, which has induced antibody production and ensures good immunity (Khedr et al., 2005). Another similar study from China (Gong et al., 2013) has reported an effective immune response in poultry birds with avian $P$. multocida OMP encoded vaccine. "C terminal fragment" of PMT has successfully been used in a recombinant DNA vaccine and has produced humoral and cellular immunity in swine (Lee et al., 2012). Keeping in view the importance of $\mathrm{HS}$ and substantial losses rendered by this disease, the present study was designed to check the effects of experimental exposure of $P$. multocida B:2 (oral) and its immunogens, i.e., LPS (oral and intravenous) and OMP (oral and subcutaneous) on clinical, hematological and serum biochemical parameters in Neeli-Ravi buffaloes.

\section{Materials and Methods}

\section{Experimental design}

In this study, the sample size consisted of prepubertal Nili Ravi female buffaloes ( $\mathrm{N}=18$ ) of $10-12$ months of age with good health conditions. They were divided into six groups from Group-1 to Group-6 (G-1 to G-6) and each group consisted of three buffaloes. G-1 animals (negative control) were treated with 10 $\mathrm{ml}$ sterile phosphate buffer saline (PBS) orally. On the other hand, $10 \mathrm{ml}$ of $10^{12}$ colony-forming unit (CFU) of P. multocida B: 2 was given orally to $\mathrm{G}-2$ animals (Chung et al., 2015). Furthermore, $10 \mathrm{ml}$ bacterial LPS extract was given to G-3 animals orally and G-4 animals intravenously (Jesse et al., 2017). At last, $10 \mathrm{ml}$ bacterial OMPs extract was inoculated subcutaneously and orally to the remaining animals of G-5 and G-6, respectively. All the experiments were conducted as per guidelines given in the animal handling manual and were approved by the ethical committee of the Department of Zoology, University of the Punjab, Lahore.

\section{Inoculum preparation}

Stock culture of $P$. multocida B:2 (used in this study) was taken from a Veterinary Research Institute, Lahore. Culturing of bacteria was done on blood agar plates with an incubation period of 24 hours at 98.6 ${ }^{\circ} \mathrm{F}$. After the culture's growth, a loopful was inoculated in nutrient broth with continuous shaking at $150 \mathrm{rpm}$ for 24 hours at $98.6^{\circ} \mathrm{F}$. Broth cultures were pooled and the purity was confirmed and the concentration was adjusted to $1 \times 10^{12}$ colony forming units (CFU) per $\mathrm{ml}$ as described by (Goldman and Green, 2015).

\section{Lipo poly saccharide (LPS) extraction from P. multocida type $B: 2$}

Lipopolysaccharide (LPS) isolation kit (MAK 339 Sigma-Aldrich USA) was used to extract LPS from the bacterial culture of $P$. multocida type B2. The kit contained LPS isolation buffer and proteinase $\mathrm{K}$. Isolated bacterial culture was grown on LB medium plate at $98.6{ }^{\circ} \mathrm{F}$ for overnight. The next day, $12 \mathrm{ml}$ of cold PBS was added to a (pre-weighed) $15 \mathrm{ml}$ conical tube. Bacterial culture was suspended in PBS as per kit instructions and centrifuged at $2500 \mathrm{x} \mathrm{g}$ for 10 minutes. The supernatant was discarded, while centrifugation was repeated. The supernatant was completely removed and Lysis buffer (in volume 10X to pellet weight) was added after weighing the pellet. The mixture was sonicated thrice for $30 \mathrm{x}$ seconds to 
disrupt the aggregates of bacteria while keeping the tube on the ice during the procedure. The tube was incubated on ice for 10 minutes. The mixture was then centrifuged at $39.2{ }^{\circ} \mathrm{F}$ for 10 minutes at $2500 \mathrm{~g}$. The lysate was transferred to a clean $1.5 \mathrm{ml}$ centrifuge tube and proteinase $\mathrm{K}$ was added. The tube was incubated at $140{ }^{\circ} \mathrm{F}$ for an hour. Afterward, it was centrifuged at $39.2^{\circ} \mathrm{F}$ for 10 minutes at $2500 \mathrm{x} g$ and the supernatant was shifted to a fresh Eppendorf tube.

Outer membrane proteins (OMP) extraction from $P$. multocida type B: 2

The first step involved freezing the freshly harvested cell pellets for $24 \mathrm{~h}$ before extraction. The cell pellets were then thawed for 15 minutes on ice and resuspended in $10 \mathrm{ml}$ of native lysis buffer. After that, incubation was done on ice for 30 minutes, followed by centrifugation at $14,000 \mathrm{rpm}$ for 30 minutes at $39.2^{\circ} \mathrm{F}$.

\section{Hematology and blood chemistry}

The blood samples were taken from the calves' jugular vein after each treatment and serum was taken after centrifugation at $10000 \mathrm{rpm}$ for 10 minutes.

Serum protein, Albumin and creatinine were measured by BioChem SA Semi-Auto Chemistry Analyzer by (High Technology, Inc Massachusetts USA) using the commercial kits (MTD diagnostics Srl, Maddaloni Italy). In contrast, RBCs, WBCs, lymphocytes, monocytes, granulocytes, $\mathrm{PCV}, \mathrm{Hgb}$, MPV, MCH and MCHC were measured by URIT2900 Vet Plus Automated Hematology Analyzer (URIT Medical Electronics, China) using reagents (URIT Medical Electronics, Guangxi541001, PR China).

\section{Clinical study}

The clinical signs such as temperature, rumen motility, respiratory rate, serous nasal discharge, recumbence, mucous membrane, salivation, edema, dullness, depression and death were checked in all the treatment groups.

\section{Statistical analysis}

The collected data was statistically analyzed by One Way ANOVA using SPSS version 24.0. The variations in different parameters with $95 \%$ confidence interval were considered statistically significant.

\section{Results and Discussion}

\section{Clinical signs and symptoms}

The clinical signs and symptoms observed in treatment groups (G-2 to G-6) were noticeable compared to the control group (G-1). The incubation periods for prepubertal buffalo calves varied according to the type and route of infection. Exposure to the bacterial culture, LPS and OMP through oral route (G-2, G-3 and $\mathrm{G}-5$, respectively) caused a high rise of body temperature up to 3 days, but after that, it remained in a constant range of $100^{\circ} \mathrm{F}-102^{\circ} \mathrm{F}$. The rumen motility was also slowed down, but the mucous membrane remained normal in these three groups. There was a high rise in body temperature for five days in animals treated with LPS through an intravenous route (G4). Afterward, the rectal temperature of G-4 animals remained constant between the ranges of $100^{\circ} \mathrm{F}$ $102^{\circ} \mathrm{F}$. The mucous membrane of these animals was congested slightly and indigestion was also observed. Among OMP through subcutaneous route animals (G-6), the temperature noted after 2 hours was $106.5^{\circ} \mathrm{F}$. It remained constant at $104^{\circ} \mathrm{F}$ for 12 hours. These animals exhibited respiratory distress, absence of rumen motility and submandibular edema after 24 hours of inoculation. These animals died after 60 hours on average. The serous nasal discharge was seen among animals after 4 to 6 hours of immunogenic treatment of all groups except $\mathrm{G}-4$.

Mild dyspnea and normal posture were observed in all treatment groups except G-6 as the illness was acute in these animals. There were no observed clinical signs in control group $\mathrm{G}-1$. The major clinical signs and symptoms observed in prepubertal female buffalo calves following inoculation with $P$. multocida $\mathrm{B}: 2$ and its immunogens (LPS and OMP) are summarized in Table 1.

\section{Hematology and serum biochemistry}

The mean value of RBCs, WBCs, lymphocytes, monocytes and granulocytes were significantly higher among all treatment groups as compared to the control. PCV, $\mathrm{Hgb}, \mathrm{MPV}$ and $\mathrm{MCH}$ also exhibited a similar trend. $\mathrm{MCHC}$ was also higher in treatment groups, but the difference among $G$ $-1, G-5$ and control were not statistically significant $((P>0.05)$. Platelet count was significantly decreased $(\mathrm{P}<0.05)$ among all treatment groups compared to the control. OMP treatment groups $(\mathrm{G}-4$ and $\mathrm{G}-5)$ showed the highest increase in WBCs count than 
other treatment groups and control. These differences were statistically significant. The change in Hgb was significantly greater in the LPS-IV (G-4) treated animals compared to all other groups. The details of changes in hematological parameters of treatment groups have been illustrated in Table 2 .

Table 1: Clinical signs observed in Neeli-Ravi buffaloes inoculated with P. multocida B:2 and its Immunogens (LPS and $O M P$ ) through various routes.

\begin{tabular}{|c|c|c|c|c|c|c|}
\hline \multirow{2}{*}{$\begin{array}{l}\text { Clinical } \\
\text { Parameters }\end{array}$} & \multirow{2}{*}{$\begin{array}{l}\text { Control } \\
\text { G-1 }\end{array}$} & Bacterial culture & \multicolumn{2}{|l|}{ LPS } & \multicolumn{2}{|l|}{ OMP } \\
\hline & & Oral route G-2 & Oral route G-3 & $\begin{array}{l}\text { Intravenous } \\
\text { route } \mathrm{G}-4\end{array}$ & $\begin{array}{l}\text { Oral route } \\
\text { G-5 }\end{array}$ & Subcutaneous route G-6 \\
\hline Death & $\begin{array}{l}\text { Survived } \\
\text { for } 21 \\
\text { days }\end{array}$ & $\begin{array}{l}\text { Alive up to } 21 \text { days } \\
\text { after infection }\end{array}$ & $\begin{array}{l}\text { Alive up to } 21 \text { days } \\
\text { after infection. }\end{array}$ & $\begin{array}{l}\text { Alive up to } 21 \\
\text { days after infec- } \\
\text { tion. }\end{array}$ & $\begin{array}{l}\text { Live for } 21 \text { days } \\
\text { after infection. }\end{array}$ & Alive for 60 hours only. \\
\hline $\begin{array}{l}\text { Temperature } \\
\text { (Temp) }\end{array}$ & Normal & $\begin{array}{l}\text { High rise of rectal } \\
\text { temp for initial } \\
3 \text { days but after- } \\
\text { wards, it lowered } \\
\text { down to } 100- \\
102^{\circ} \mathrm{F} \text {. }\end{array}$ & $\begin{array}{l}\text { High rise of rectal } \\
\text { temp for initial } 3 \\
\text { days but afterward } \\
\text { lowered down to } \\
100-102^{\circ} \mathrm{F} \text {. }\end{array}$ & $\begin{array}{l}\text { High rise of } \\
\text { rectal temp for } \\
\text { the initial } 5 \text { days } \\
\text { but afterward } \\
\text { lowered down to } \\
100-102^{\circ} \mathrm{F} \text {. }\end{array}$ & $\begin{array}{l}\text { High rise of } \\
\text { rectal temp for } \\
\text { initial } 3 \text { days but } \\
\text { afterwards, it } \\
\text { lowered down to } \\
100-102^{\circ} \mathrm{F} \text {. }\end{array}$ & $\begin{array}{l}\text { Temp noted after } 2 \text { hours } \\
\text { was } 106.5^{\circ} \mathrm{F} \text {. } \\
\text { The temperature remained } \\
\text { constant at } 104^{\circ} \mathrm{F} \text { for } 12 \\
\text { hours. }\end{array}$ \\
\hline $\begin{array}{l}\text { Rumen } \\
\text { motility }\end{array}$ & Normal & $\begin{array}{l}\text { Rumen motility } \\
\text { slight slowdown. }\end{array}$ & $\begin{array}{l}\text { Rumen motility } \\
\text { slight slowdown. }\end{array}$ & Indigestion. & $\begin{array}{l}\text { Rumen motility } \\
\text { slight slowdown. }\end{array}$ & $\begin{array}{l}\text { Absence of rumen motility } \\
\text { after } 24 \text { hours of infection. }\end{array}$ \\
\hline Respiration & $\begin{array}{l}\text { Normal } \\
\text { Range }\end{array}$ & Mild dyspnea. & Mild dyspnea. & Mild dyspnea. & Mild dyspnea. & $\begin{array}{l}\text { Severe dyspnea started after } \\
24 \text { hours of infection. }\end{array}$ \\
\hline $\begin{array}{l}\text { Mucous } \\
\text { membrane } \\
\text { (MM), } \\
\text { Salivation } \\
\text { Edema and } \\
\text { Dullness }\end{array}$ & Normal & Normal MM. & Normal MM. & $\begin{array}{l}\text { Slightly congest- } \\
\text { ed MM. }\end{array}$ & Normal MM. & $\begin{array}{l}\text { MM was congested after } 6 \\
\text { hours of infection, Subman- } \\
\text { dibular edema extending } \\
\text { up to the brisket region and } \\
\text { dullness seen after } 24 \text { hours } \\
\text { of infection. }\end{array}$ \\
\hline $\begin{array}{l}\text { Serous nasal } \\
\text { discharge }\end{array}$ & $\begin{array}{l}\text { No nasal } \\
\text { dis- } \\
\text { charge. }\end{array}$ & $\begin{array}{l}\text { For the initial } 4 \\
\text { days of infection } \\
\text { only. }\end{array}$ & $\begin{array}{l}\text { For the initial } 4 \\
\text { days of infection } \\
\text { only. }\end{array}$ & $\begin{array}{l}\text { For the initial } 5 \\
\text { days of infection } \\
\text { only. }\end{array}$ & $\begin{array}{l}\text { No nasal dis- } \\
\text { charge. }\end{array}$ & $\begin{array}{l}\text { Seen after } 6 \text { hours of infec- } \\
\text { tion. }\end{array}$ \\
\hline Recmbency & None. & Normal posture & Normal posture. & Normal posture & Normal posture & $\begin{array}{l}\text { Animals collapsed after } 36 \\
\text { hours. }\end{array}$ \\
\hline
\end{tabular}

Table 2: Hematological profile of Neeli-Ravi buffaloes inoculated with P. multocida B:2 and its Immunogens (LPS and $O M P$ ) through various routes.

\begin{tabular}{|c|c|c|c|c|c|c|}
\hline Treatment & Control & Culture & LPS & & OMP & \\
\hline Parameter/ Group & PBS & PO & $\mathrm{PO}$ & IV & $\mathrm{PO}$ & $\mathrm{S} / \mathrm{C}$ \\
\hline PCV (\%) & $34.33 \pm 0.88^{a}$ & $53.60 \pm 0.92^{\mathrm{b}}$ & $47.77 \pm 1.94^{\mathrm{c}}$ & $51.67 \pm 1.60 \mathrm{bc}$ & $47.93 \pm 1.90 c$ & $52.03 \pm 1.25 \mathrm{bc}$ \\
\hline $\operatorname{Hgb}(g / L)$ & $10.67 \pm 0.24 \mathrm{a}$ & $13.63 \pm 0.38^{\mathrm{b}}$ & $14.03 \pm 0.29^{\text {bde }}$ & $15.70 \pm 0.65^{c}$ & $13.90 \pm 0.57^{\mathrm{d}}$ & $15.37 \pm 0.46^{\text {ce }}$ \\
\hline $\mathrm{RBCs}\left(\mathrm{x} 10^{12} / \mathrm{L}\right)$ & $8.10 \pm 0.35 \mathrm{a}$ & $10.77 \pm 0.22_{\mathrm{b}}$ & $11.33 \pm 0.13^{\mathrm{bc}}$ & $11.47 \pm 0.37 \mathrm{bc}$ & $11.90 \pm 0.06^{\mathrm{c}}$ & $12.33 \pm 0.47^{\mathrm{c}}$ \\
\hline $\operatorname{MCV}(\mathrm{fl})$ & $43.33 \pm 2.90^{\mathrm{a}}$ & $35.50 \pm 1.80^{\mathrm{b}}$ & $34.43 \pm 0.82^{\mathrm{b}}$ & $35.77 \pm 0.96^{\mathrm{b}}$ & $37.60 \pm 1.25^{\mathrm{b}}$ & $35.33 \pm 0.77^{\mathrm{b}}$ \\
\hline $\mathrm{MCH}(\mathrm{pg})$ & $13.53 \pm 0.35^{a}$ & $16.80 \pm 0.26^{b}$ & $17.63 \pm 0.79^{b}$ & $17.10 \pm 0.17^{b}$ & $17.63 \pm 0.26^{b}$ & $18.16 \pm 0.49^{b}$ \\
\hline $\mathrm{MCHC}(\mathrm{g} / \mathrm{L})$ & $32.50 \pm 2.18^{\mathrm{a}}$ & $35.33 \pm 3.05^{\mathrm{ab}}$ & $37.00 \pm 1.73^{\mathrm{b}}$ & $36.83 \pm 2.75^{\mathrm{b}}$ & $36.57 \pm 2.10^{\mathrm{b}}$ & $35.30 \pm 1.10^{\mathrm{ab}}$ \\
\hline Platelets $\left(x 10^{9} / \mathrm{L}\right)$ & $526.00 \pm 51.03^{a}$ & $294.33 \pm 24.36^{\mathrm{b}}$ & $312.67 \pm 26.99^{\mathrm{b}}$ & $367.67 \pm 17.97^{\mathrm{b}}$ & $358.00 \pm 17.43^{\mathrm{b}}$ & $289.33 \pm 49.64^{b}$ \\
\hline MPV (f) & $5.10 \pm 0.49^{\mathrm{a}}$ & $3.47 \pm 0.23^{b}$ & $3.33 \pm 0.20^{\mathrm{b}}$ & $3.50 \pm 0.34^{\mathrm{b}}$ & $3.13 \pm 0.22^{\mathrm{b}}$ & $3.30 \pm 0.30^{\mathrm{b}}$ \\
\hline WBCs $\left(x 10^{9} / \mathrm{L}\right)$ & $10.63 \pm 0.50^{\mathrm{a}}$ & $14.80 \pm 0.85^{\mathrm{b}}$ & $15.40 \pm 1.01^{\mathrm{b}}$ & $15.43 \pm 0.62^{\mathrm{b}}$ & $17.50 \pm 0.50^{c}$ & $17.67 \pm 0.23^{c}$ \\
\hline Monocytes (\%) & $5.40 \pm 0.70^{\mathrm{a}}$ & $8.17 \pm 0.18^{b}$ & $8.67 \pm 0.39^{\mathrm{b}}$ & $8.60 \pm 0.30^{\mathrm{b}}$ & $10.43 \pm 0.84^{c}$ & $9.70 \pm 0.77^{\mathrm{bc}}$ \\
\hline Lymphocytes (x109/L) & $5.17 \pm 0.58^{\mathrm{a}}$ & $8.27 \pm 0.37^{\mathrm{b}}$ & $8.70 \pm 0.46^{\mathrm{b}}$ & $8.77 \pm 0.23^{b}$ & $8.60 \pm 0.38^{b}$ & $8.57 \pm 0.66^{\mathrm{b}}$ \\
\hline Granulocytes (x109/L) & $6.97 \pm 0.30^{\mathrm{a}}$ & $11.00 \pm 0.61^{\mathrm{b}}$ & $11.44 \pm 0.39^{\mathrm{b}}$ & $12.27 \pm 0.98^{\mathrm{b}}$ & $11.47 \pm 0.42^{\mathrm{b}}$ & $11.73 \pm 0.14^{\mathrm{b}}$ \\
\hline
\end{tabular}

Note: Parameters in a row with different superscripts vary significantly from each other $(P<0.05)$. 
Table 3:. Blood Chemistry Profile of Neeli-Ravi buffaloes inoculated with Pasturella. multocida B:2 and its Immunogens (LPS and OMP) through various routes.

\begin{tabular}{|c|c|c|c|c|c|c|}
\hline \multirow{2}{*}{$\begin{array}{l}\text { Culture } \\
\text { Parameter }\end{array}$} & \multicolumn{4}{|c|}{ OMP } & \multirow[b]{2}{*}{$\mathrm{PO}$} & \multirow[b]{2}{*}{$\mathrm{S} / \mathrm{C}$} \\
\hline & PBS & PO & $\mathrm{PO}$ & IV & & \\
\hline Serum Protein (g/L) & $7.00 \pm 0.15^{\mathrm{a}}$ & $8.47 \pm 0.18^{\mathrm{b}}$ & $8.63 \pm 0.23^{\mathrm{bc}}$ & $9.03 \pm 0.29^{b}$ & $8.97 \pm 0.62^{b}$ & $8.07 \pm 0.14^{c}$ \\
\hline Serum Albumin (g/dL) & $3.40 \pm 0.11^{\mathrm{a}}$ & $4.43 \pm 0.20^{\mathrm{b}}$ & $4.70 \pm 0.23^{\mathrm{bc}}$ & $4.97 \pm 0.46^{\mathrm{bc}}$ & $5.00 \pm 0.30^{\mathrm{bc}}$ & $5.37 \pm 0.18^{c}$ \\
\hline Serum Creatinine $(\mathrm{mg} / \mathrm{dL})$ & $1.93 \pm 0.18^{\mathrm{a}}$ & $3.60 \pm 0.26^{\mathrm{b}}$ & $3.67 \pm 0.27^{\mathrm{b}}$ & $4.10 \pm 0.36^{\mathrm{bc}}$ & $4.67 \pm 0.53^{c}$ & $4.80 \pm 0.38^{c}$ \\
\hline
\end{tabular}

Note: Parameters in a row with different superscripts vary significantly from each other $(P<0.05)$.

Blood biochemistry parameters were also significantly disturbed among all treatment groups as compared to the control. The highest serum protein value $(9.03 \pm 0.29)$ was observed in the LPS-Intravenous group (G-3). The mean value of serum protein remained significantly higher in treatment groups as compared to control. The highest serum albumin and creatinine value were $5.37 \pm 0.18$ and $4.80 \pm 0.38$, respectively, observed in the OMP-S/C group (G-6). Cumulatively, serum albumin and creatinine's mean values were also significantly $(\mathrm{P}<0.05)$ higher among treatment groups than the control. The detailed summary of blood biochemistry results has been illustrated in Table 3.

In this study, changes in clinical, hematological and serum biochemical parameters in Neeli-Ravi buffaloes due to experimental exposure of $P$. multocida $\mathrm{B}: 2$ culture (orally) and its immunogens, i.e., LPS (orally and intravenous) and OMP (orally and subcutaneous) were documented for the first time in Pakistan.

Although P. multocida B:2 affects both cattle and buffaloes, but later are more susceptible to HS compared to cattle (Zamri-Saad and Annas, 2016). During natural infection, the pathogen enters through the oral or intranasal route. It causes acute infection in the lungs and then crosses blood capillaries through endothelial cells to produce septicemia (Puspitasari et al., 2020). This disease causes very acute respiratory and systemic signs (De Alwis, 1999).

According to our study, all treatment groups of buffaloes exhibited characteristic clinical signs of HS. These signs were ranging from mild to very acute in severity. The rise in rectal temperature lowered rumen motility and distress to the respiratory system were common observations among all the treatment groups. However, clinic signs' exhibition remained considerably higher in LPS-intravenous $(\mathrm{G}-4)$ and OMP-subcutaneous (G-6) animals. Animals from these two groups exhibited congestion of mucous membrane as well. In the latter group (OMPsubcutaneous), the development of submandibular edema and even one animal's death within 60 hours was also witnessed.

Although there is no constant pattern of hematological response by the host towards an experimental exposure of a gram-negative bacteria and its immunogens, however significant changes in hematological parameters of experimental buffaloes are suggestive of reaction by the immune system of buffaloes towards experimental exposure of $P$. multocida and its immunogens (LPS and OMP).

WBCs are involved in the defense mechanism against infectious agents. WBCs include neutrophils, lymphocytes, monocytes, eosinophils and granulocytes. A significant increase in circulating WBCs was observed. Previous studies also showed that change in WBCs was due to bacterial infection (Steven, 2000; Todar, 2008). RBCs are involved in Oxygen transport and the term "polycythemia" is used for the increased number of red blood cells. In treatment groups, significant polycythemia was observed as compared to the control group. However, the mean $\mathrm{RBC}$ value for all treatment groups was not too high compared with the normal range of $\mathrm{RBCs}$ in buffaloes. Hence no specific conclusion may be associated with this polycythemia. Platelet count and MPV were decreased in experiment groups. It was indicative of thrombocytopenia due to experimental exposure to $P$. multocida and its immunogens. However, this change was within the acceptable (100 to $800 \times 10^{9} / \mathrm{L}$ ) range (Roland et al., 2014).

Serum protein, Albumin and creatinine have high value in disease diagnosis. The serum protein and Albumin of all treatment groups were on the higher side $(\mathrm{P}<0.05)$ compared to control. High serum protein indicates inflammatory reactions or some infection, while the increased serum albumin values indicate an immunogenic response by the animals, 
as observed in case of acute infections. A high level of creatinine generally indicates dehydration or some kidney disease. Although serum creatinine values were significantly higher among treatment groups than control $(\mathrm{P}<0.05)$, they can only be correlated to systemic inflammatory response due to immunogenic treatment. Other studies also suggested that creatinine increases during pasteurellosis (Seleim et al., 2003; Kamal, 2010).

P. multocida B:2 inoculation ( $10 \mathrm{ml}$ of $10^{12} \mathrm{CFU} / \mathrm{ml}$ ) through subcutaneous and oral routes on buffaloes (Chung et al., 2015) has been correlated with clinical signs, changes in hematology and histopathology. These changes are consistent with results exhibited by G-2 (P. multocida oral inoculation group) animals of our study. Endotoxin properties of P. multocida B:2 LPS extract were confirmed by its intravenous exposure in buffaloes (Horadagoda et al., 2002). A similar study has affirmed changes in clinical signs, hematology and histopathology on experimental exposure to LPS-extract of $P$. multocida $\mathrm{B}: 2$ via the oral and intravenous route in buffaloes (Chung et al., 2016). Immunogenicity studies of OMP of $P$. multocida in buffalo calves have suggested a positive immune response (Pati et al., 1996).

Intranasal and subcutaneous exposure of rabbits to $P$. multocida resulted in HS's clinical signs (Leghari et al., 2016). Immunogenic response on experimental exposure to LPS of $P$. multocida in rabbits has also been reported from Pakistan (Ashraf et al., 2014). Recently a recombinant OMP based intranasal vaccine has been successfully experimented in swamp buffaloes against HS (Muenthaisong et al., 2020).

\section{Conclusions and Recommendations}

Hemorrhagic septicemia is a very lethal disease of bovines in tropical countries caused by $P$. multocida type B:2. This study provided clear evidence that experimental exposure of $P$. multocida type B:2 culture (orally) and its immunogens, i.e., LPS (orally and intravenous) and OMP (orally and subcutaneous), produces significant changes in clinical, hematological and serum biochemical parameters in Neeli-Ravi buffaloes. This influence warrants further investigation to use LPS and OMP of P. multocida B: 2 as an alternate option for vaccine production against $\mathrm{HS}$ in bovines.

\section{Novelty Statement}

The study provides clear evidence of immunogenic response in Nili Ravi buffaloes by LPS and OMP extract of P.multocida B:2 and hints about their use as an alternate source of vaccination.

\section{Author's Contribution}

Ali Zaman: Conducted the experiments.

Nabila Rohi: Supervised the study.

Muhammad Irfan: Interpreted the data and wrote the manuscript.

\section{Conflict of interest}

The authors have declared no conflict of interest.

\section{References}

Anonymous. 2019-20. Economic Survey of Pakistan, Government of Pakistan, Islamabad, Pakistan.

Annas, S., M. Abubakar, M. Zamri-Saad, F. Jesse and Z. Zunita. 2015. Pathological changes in the respiratory, gastrointestinal and urinary tracts of buffalo calves following experimental hemorrhagic septicemia. Pak. Vet. J., 35(4): 430-435.

Ashraf, A., S. Mahboob, K. Al-Ghanim, T. Huma and M. Shah. 2014. Immunogenic activity of lipopolysaccharides from Pasteurella multocida in rabbits.J. Anim. Plant Sci., 24(6): 1780-1785.

Benkirane, A. and M. De Alwis, 2002. Haemorrhagic septicaemia, its significance, prevention and control in asia. Vet. Med. Praha., 47(8): 234-240. https://doi.org/10.17221/5830VETMED

Biswas, A., S. Shivachandra, M. Saxena, A. Kumar, V. Singh and S. Srivastava. 2004. Molecular variability among strains of Pasteurella multocida isolated from an outbreak of haemorrhagic septicaemia in india. Vet. Res. Comm., 28(4): 287-298. https://doi.org/10.1023/ B:VERC.0000026656.77847.5b

Boyce,J.D. and B. Adler. 2006. How does Pasteurella multocida respond to the host environment? Curr. Opin. Microbiol., 9(1): 117-122. https:// doi.org/10.1016/j.mib.2005.12.005

Chung, E.L.T., F.F.J. Abdullah, L. Adamu, A.D. Marza, H.H. Ibrahim, M. Zamri-Saad, A.W. 
Haron, A.A. Saharee, M.A.M. Lila and A.R. Omar. 2015. Clinico-pathology, hematology, and biochemistry responses toward Pasteurella multocida type b: 2 via oral and subcutaneous route of infections. Vet.World, 8(6): 783.https:// doi.org/10.14202/vetworld.2015.783-792

Chung, E.L.T., F.F.J. Abdullah, H.H. Ibrahim, A.D. Marza, M. Zamri-Saad, A.W. Haron, M.A.M. Lila and M.J. Norsidin, 2016. Clinico-pathology, hematology and biochemistry responses in buffaloes towards Pasteurella multocida type B: 2 immunogen lypopolysaccharide via oral and intravenous routes of infection. Microbial Pathog., 91: 141-154. https://doi. org/10.1016/j.micpath.2015.12.003

De Alwis, M., 1999. Haemorrhagic septicaemia. Aciar monograph no. 57. Australian Center for International Agricultural Research, Canberra, Australia.

Goldman, E. and L.H. Green. 2015. Practical handbook of microbiology. CRC press. https:// doi.org/10.1201/b17871

Gong, Q. N. Qu, M. Niu, C. Qin, M. Cheng, X. Sun and A. Zhang. 2013. Immune responses and protective efficacy of a novel DNA vaccine encoding outer membrane protein of avian pasteurella multocida. Vet. Immunol. Immunopathol., 152(3-4): 317-324. https:// doi.org/10.1016/j.vetimm.2013.01.001

Harper,M.,J.D.Boyce and B.Adler.2006. Pasteurella multocida pathogenesis: 125 years after pasteur. FEMS Microbiol. Lett., 265(1): 1-10. https:// doi.org/10.1111/j.1574-6968.2006.00442.x

Harper, M., A.D. Cox, B. Adler and J.D. Boyce, 2011. Pasteurella multocida lipopolysaccharide: The long and the short of it. Vet. Microbiol., 153(1-2): 109-115. https://doi.org/10.1016/j. vetmic.2011.05.022

Horadagoda, N., J. Hodgson, G. Moon, T. Wijewardana and P. Eckersall. 2002. Development of a clinical syndrome resembling haemorrhagic septicaemia in the buffalo following intravenous inoculation of Pasteurella multocida serotype B: 2 endotoxin and the role of tumour necrosis factor- $\alpha$. Res. Vet. Sci., 72(3): 194-200. https://doi.org/10.1053/ rvsc. 2001.0538

Ibrahim,H.H., F.F.J.Abdullah, E.L.T.Chung,A.D. Marza, M.Z. Saad, A.W. Haron and M.A.M. Lila. 2016. Clinical and histopathological study on reproductive lesions caused by Pasteurella multocida type $\mathrm{B}: 2$ immunogens in buffalo heifers. Bull. J. Vet. Med., 21(2): 1-10. https:// doi.org/10.15547/bjvm.969

Iovane, G., P. Pagnini, M. Galdiero, G.C. de l'Ero, M. Vitiello, M. D'Isanto and A. Marcatili. 1998. Role of Pasteurella multocida porin on cytokine expression and release by murine splenocytes. Vet. Immunol. Immunopathol., 66(3-4): 391-404. https://doi.org/10.1016/ S0165-2427(98)00183-4

Jesse, F.F.A., H.H. Ibrahim, Y.Abba,E.L.T.Chung, A.D. Marza, M. Mazlan, M. Zamri-Saad, A.R. Omar, M.Z.A.B. Zakaria and A.A. Saharee, 2017. Reproductive hormonal variations and adenohypophyseal lesions in pre-pubertal buffalo heifers inoculated with Pasteurella multocida type B: 2 and its immunogens. BMC Vet. Res., 13(1): 1-10. https://doi.org/10.1186/ s12917-017-1010-y

Kamal, A.M., 2010. Some biochemical, hematological and clinical studies of selected ruminal and blood constituents in camels affected by various diseases. Res. J. Vet. Sci., 3(1): 28-39.

Khedr, A., L. Omar, Y. Soliman, M. Metwalli, E. Ebiary, J. El-Jakkee and M. Refai. 2005. Protective efficacy of plasmid DNA vaccine coding omph gene of Pasteurella multocida. Proc. 2d Intern. Conf. Vet. Res. Div. NRC, Cairo, Egypt. pp. 97-118.

Kubatzky, K.F., 2012. Pasteurella multocida and immune cells. Curr. Top Microbiol. Immunol., 361: 53-72. https://doi. org/10.1007/82_2012_204

Lee,J., H.-E. Kang and H.-J.Woo. 2012. Protective immunity conferred by the c-terminal fragment of recombinant Pasteurella multocida toxin. Clin. Vac. Immunol., 19(9): 1526-1531. https://doi. org/10.1128/CVI.00238-12

Leghari, M., Z. Nizamani, I. Leghari, T. Samo, A. Sethar and F. Samo. 2016. Hemato-biochemical and pathological studies on induced pastuerella multocida infection in rabbits. Sindh Univ. Res. J., (Sci. Ser.), 48(3).

Muenthaisong, A., B. Nambooppha, A. Rittipornlertrak, P. Tankaew, T. Varinrak, K. Muangthai, K. Atthikanyaphak, T. Sawada and N. Sthitmatee. 2020. An intranasal vaccination with a recombinant outer membrane protein $h$ against haemorrhagic septicemia in swamp buffaloes. Vet. Med. Int., 2020. https://doi. 
org/10.1155/2020/3548973

OIE. 2009. Haemorrhagic septicaemia, Chapter 2.4.12. Terrestrial manual. Paris, France. pp. 739-750.

Othman, A., Y. Abba, F. Jesse, Y. Ilyasu, A. Saharee, A. Haron, M. Zamri-Saad and M. Lila. 2016. Reproductive pathological changes associated with experimental subchronic corynebacterium pseudotuberculosis infection in nonpregnant boer does. J. Pathol., 2016: 4624509. https:// doi.org/10.1155/2016/4624509

Pati, U., S. Srivastava, S. Roy and T. More. 1996. Immunogenicity of outer membrane protein of pasteurella multocida in buffalo calves. Vet. Microbiol., 52(3-4): 301-311. https://doi. org/10.1016/S0378-1135(96)00066-1

Puspitasari, Y., A. Salleh and M. Zamri-Saad, 2020. Ultrastructural changes in endothelial cells of buffaloes following in-vitro exposure to Pasteurella multocida B: 2. BMC Vet. Res., 16(1): 1-9. https://doi.org/10.1186/s12917020-02415-2

Rafidah, O., M. Zamri-Saad, E. Nasip, S. Shahiruddin and A. Saharee. 2010. Analysis of haemorrhagic septicaemia outbreaks in cattle and buffalo in malaysia. Online J. Vet. Res., 14(2): 325-333.

Ramdani,H.D., R.Johnson, T. Spencer and B.Adler. 1990. Pasteurella multocida infections in mice with reference to haemorrhagic septicaemia in cattle and buffalo. Immunol. Cell Biol., 68(1): 57-61. https://doi.org/10.1038/icb.1990.8

Roland, L., M. Drillich and M. Iwersen. 2014. Hematology as a diagnostic tool in bovine medicine. J. Vet. Diagn. Invest., 26(5): 592-598. https://doi.org/10.1177/1040638714546490

Saad, M.Z., Z. Zakaria, R. Abdullah and A.A. Saharee. 2013. Acute phase protein profile and clinico-pathological changes in mice associated with the infection of Pasteurella multocida type $\mathrm{b}$ and the bacterial lipopolysaccharide and outer membrane protein imminogens. J. Anim. Vet. Adv., 12(2): 186-193.

Seleim, R., R. Amal, R. Sahar, H. Nada and R. Gobran. 2003. Elisa and other tests in the diagnosis of Pasteurella multocida infection in camels. Deutscher Tropentag, International Research on Food Security, Natural Resource Management and Rural Development GeorgAugust-Universität Göttingen.

Shivachandra, S., K. Viswas and A. Kumar, 2011. A review of hemorrhagic septicemia in cattle and buffalo. Anim. Health Res. Rev., 12(1): 67. https://doi.org/10.1017/S146625231100003X

Steven, L., 2000. Hematologic changes due to bacterial infections. Schalms's Veterinary Hematology. $5^{\text {th }}$ ed. Lippincott Williams and Wilkins, USA.

Todar, K., 2008. Pathogenic escherichia coli.Todar's Online Textbook on Bacteriology. pp. 579.

Wilson,B.A. and M.Ho.2013.Pasteurella multocida: From zoonosis to cellular microbiology. Clin. Microbiol. Rev., 26(3): 631-655. https://doi. org/10.1128/CMR.00024-13

Zamri-Saad, M. and S. Annas, 2016. Vaccination against hemorrhagic septicemia of bovines: A review. Pak. Vet. J., 36(1): 1-5. 